Article

\title{
Insentek Sensor: An Alternative to Estimate Daily Crop Evapotranspiration for Maize Plants
}

\author{
Anzhen Qin ${ }^{1}$, Dongfeng Ning ${ }^{1, *}$, Zhandong Liu ${ }^{1, *}$, Bin Sun ${ }^{2}$, Ben Zhao ${ }^{1}$, Junfu Xiao ${ }^{1}$ and \\ Aiwang Duan ${ }^{1}$ \\ 1 Key Laboratory of Crop Water Use and Regulation, Ministry of Agriculture and Rural Affairs, \\ Farmland Irrigation Research Institute, Chinese Academy of Agricultural Sciences, Xinxiang 453002, China; \\ qinanzhen@126.com (A.Q.); zhaoben@caas.cn (B.Z.); xiaojunfu@caas.cn (J.X.); duanaiwang@caas.cn (A.D.) \\ 2 Xuchang Experiment and Extension Station of Farmland Water Conservancy, Xuchang 461000, China; \\ xcsyzsun@163.com \\ * Correspondence: ningdongfeng@caas.cn (D.N.); liuzhandong@caas.cn (Z.L.); Tel.: +86-373-339-3321 (Z.L.)
}

Received: 25 November 2018; Accepted: 17 December 2018; Published: 24 December 2018

check for updates

\begin{abstract}
Estimation of ground-truth daily evapotranspiration $\left(\mathrm{ET}_{\mathrm{c}}\right)$ is very useful for developing sustainable water resource strategies, particularly in the North China Plain (NCP) with limited

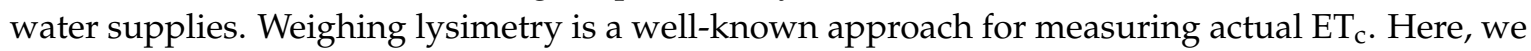
introduced an alternative to lysimetry for $\mathrm{ET}_{\mathrm{C}}$ determination using Insentek sensors. A comparison experiment was conducted for maize plants at Xuchang Irrigation Experiment Station, in the NCP, in 2015 and 2016. Insentek $\mathrm{ET}_{\mathrm{C}}$ was evaluated using data on clear days and rainy days independently. We found that daily $\mathrm{ET}_{\mathrm{C}}$ increased gradually from VE (emergence) to VT (tasseling) stages, peaked at the R1 (silking) stage with the highest value of $7.8 \mathrm{~mm} \cdot \mathrm{d}^{-1}$, and then declined until maturity. On average, cumulative total of lysimetric $\mathrm{ET}_{\mathrm{c}}$ was 19\% higher than that of Insentek $\mathrm{ET}_{\mathrm{c}}$. The major depth of soil water extraction might be $60 \mathrm{~cm}$ for maize plants on lysimeters according to soil water depletion depth monitored by Insentek sensors. Daily $\mathrm{ET}_{\mathrm{C}}$ significantly related to soil water content (SWC) in topsoil $(0-30 \mathrm{~cm})$ in an exponential function (coefficients of determination $\left(\mathrm{R}^{2}\right)=0.32-0.53$ ), and to precipitation (Pre) in a power function $\left(\mathrm{R}^{2}=0.84-0.87\right)$. The combined SWC $(0-30 \mathrm{~cm})-\mathrm{Pre}-\mathrm{ET}_{\mathrm{C}}$ model may offer significant potential for accurate estimation of maize $\mathrm{ET}_{\mathrm{C}}$ in semi-humid environment of the NCP.
\end{abstract}

Keywords: water balance; automatic soil moisture record; lysimetry; North China Plain; Zea mays L.

\section{Introduction}

The North China Plain (NCP) produces 58 and 33\% of the domestic wheat and maize yields in China, ensuring China's food security [1]. In 2016, maize (Zea mays L.), with a total yield of 220 million tons, was planted on a 36 million hectare across China, making a $49 \%$ contribution to domestic increase in grain production [2]. Maize is also known as one of the highest water-using crops in different regions $[3,4]$. Thanks to a continent monsoon climate, annual precipitation falls between 400 and $600 \mathrm{~mm}$ in the NCP, with $65 \%$ of precipitation occurring in maize seasons [5], while annual evapotranspiration ranges from 800 to $900 \mathrm{~mm}$ : 50-100\% higher than precipitation [6]. For decades, crop water consumption has been being supplemented by extracting the declining groundwater in the NCP at a speed exceeding aquifer recharge [7]. In the future, immense volumes of groundwater will be required for the agricultural sector with an ever-growing population [8]. Nevertheless, agronomic practices, such as cultivar updating and irrigation optimizing, have been made to extend the life of the aquifer. Consequently, only a $10 \%$ increase in crop evapotranspiration $\left(\mathrm{ET}_{\mathrm{C}}\right)$ contributed to a $50 \%$ 
yield increase over the past two decades [9]. Of those practices, $\mathrm{ET}_{\mathrm{c}}$-based irrigation scheduling is considered a powerful tool to decrease long-term aquifer extraction [10].

In general, $\mathrm{ET}_{\mathrm{c}}$ is the process where water is consumed through soil evaporation and plant transpiration during the water cycling [11]. It has always been considered as an equivalent to crop water use [12]. Water balance equation is the most widely used method to estimate $\mathrm{ET}_{\mathrm{c}}$. In the equation, $\mathrm{ET}_{\mathrm{C}}$ stands for water loss from soil surface and plants whereas precipitation and irrigation represents water input. Water-saving strategies largely depend on the monitoring and controlling of $\mathrm{ET}_{\mathrm{c}}[5,6]$. There are numerous methods available for estimating $\mathrm{ET}_{\mathrm{c}}[12-15]$, among which weighing lysimetry is normally used as a standard means [16]. However, its construction is expensive and its operation requires professional personnel [17]. This restricts the popularity of lysimetry. Alternatives should be developed to facilitate $\mathrm{ET}_{\mathrm{c}}$ monitoring. $\mathrm{ET}_{\mathrm{c}}$ estimation based on the oven-drying method is simple; however, it is laborious and time-consuming [4]. Another way is to adopt the neutron probe method [18]. This enables the estimation of $\mathrm{ET}_{\mathrm{c}}$ regardless of crop types and soil properties. However, this method usually needs a span of time to measure soil water content (SWC), and is difficult to estimate daily or sub-daily $\mathrm{ET}_{\mathrm{c}}[19]$. Another approach for $\mathrm{ET}_{\mathrm{c}}$ estimation is remote sensing technology. It enables us to use satellite observations to estimate $\mathrm{ET}_{\mathrm{C}}$ at a global and regional scale [20]. However, studies have shown that different algorithms of remote sensing models for $\mathrm{ET}_{\mathrm{c}}$ estimation have strong divergence [21]. Usually, the algorithms to estimate $\mathrm{ET}_{\mathrm{c}}$ have been based on a surface energy budget using thermal infrared data, which required plenty of ground-based measurements and were affected by cloud contamination, providing uncertainties to the $\mathrm{ET}_{\mathrm{c}}$ estimates [21,22]. Therefore, a real-time ground-truth monitoring of $\mathrm{ET}_{\mathrm{C}}$ is needed.

The Insentek sensor (Beijing Oriental Ecological Technology Ltd., Co., Beijing, China) is an emerging technology that can automatically monitor soil moisture data hourly or sub-hourly (Figure 1). It is an apparatus for real-time soil moisture monitoring powered by solar energy. Insentek sensor allows the determination of daily changes in soil water storage (SWS), making the calculation of daily $\mathrm{ET}_{\mathrm{c}}$ possible. Our previous study showed that root mean square error (RMSE) of SWC between the Insentek sensor and the oven-dry method was $0.927 \mathrm{~cm}^{3} \cdot \mathrm{cm}^{-3}$, and relative prediction deviation (RPD) was 7.99 for silt loamy soils, indicating Insentek sensor is a reliable tool to represent real SWC values (Table 1). The latest figure have shown that there have been more than 15,000 sensors already installed across China, including remote areas such as Tibet (personal communication). An $\mathrm{ET}_{\mathrm{c}}$ monitoring network that covers the whole country has been formed. Through checking the year-round data, Insentek sensors have showed better continuity and stability than other soil moisture techniques (e.g., time-domain reflectometry, neutron probe, and oven-drying etc.). In this study, weighing lysimeters were adopted to continuously monitor $\mathrm{ET}_{\mathrm{c}}$ of summer maize along with Insentek sensors.

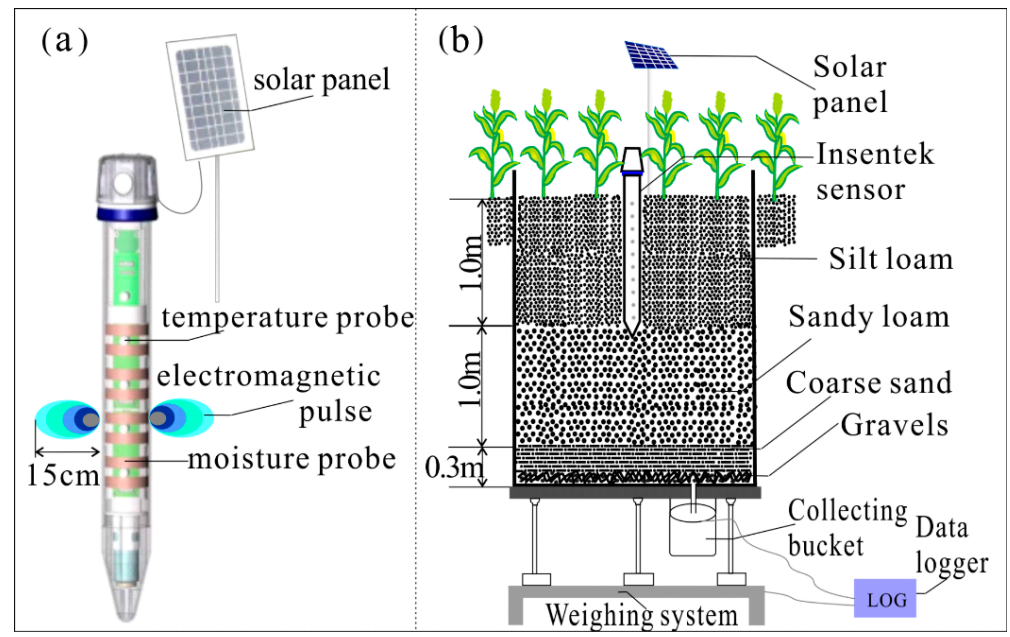

Figure 1. Insentek sensor and design of lysimeter experiment. (a) The structure and principle of an Insentek sensor; (b) lysimeter setup details and installation of an Insentek sensor. 
Table 1. Test for goodness of fit between soil water content (soil water content (SWC), $\mathrm{cm}^{3} \cdot \mathrm{cm}^{-3}$ ) measured using an Insentek sensor and oven-dry method across different soil textures.

\begin{tabular}{cccccccc}
\hline \multirow{2}{*}{$\begin{array}{c}\text { Soil } \\
\text { Texture }\end{array}$} & \multicolumn{2}{c}{ SWC Measured by Insentek Sensor } & \multicolumn{2}{c}{ Goodness of Fit } & \multicolumn{2}{c}{ Correlation } & \multicolumn{2}{c}{ Significance } \\
\cline { 2 - 8 } & Maximum & Minimum & Mean & RMSE & RPD & $\mathbf{R}^{\mathbf{2}}$ & $\boldsymbol{p}$ \\
\hline Sand & 3.46 & 28.64 & 18.09 & 1.044 & 6.78 & 0.997 & 0.0001 \\
Silt loam & 7.26 & 35.11 & 22.71 & 0.927 & 7.99 & 0.995 & 0.0001 \\
Clay & 17.74 & 33.71 & 25.35 & 0.897 & 5.61 & 0.997 & 0.0001 \\
\hline
\end{tabular}

RMSE is root mean square error used to evaluate the differences between estimated and observed SWC; RPD is relative prediction deviation, values measured by Insentek sensor are reliable with $R P D \geq 2.0$ [23]; $R^{2}$ is coefficient of determination; $p$ is probability.

Until now, the degree to which $\mathrm{ET}_{\mathrm{c}}$ from Insentek sensor method represents that of the lysimetry has not been well tested. In this study, we started the comparison work between the two. Moreover, precipitation was recorded by a nearby weather station to analyze the relationship between $\mathrm{ET}_{\mathrm{c}}$ and precipitation. We hypothesized that $\mathrm{ET}_{\mathrm{c}}$ from the Insentek sensor method was similar to that of lysimetry, and that $\mathrm{ET}_{\mathrm{c}}$ was significantly related to precipitation and soil moisture. The objectives of this study were to evaluate the efficacy of Insentek sensor method using lysimetric data, and to quantify the relationships among $\mathrm{ET}_{\mathrm{C}}, \mathrm{SWC}_{\mathrm{S}}$ and precipitation for maize plants in the NCP.

\section{Materials and Methods}

\subsection{Site Description}

The experiment was carried out at the Xuchang Irrigation Experiment Station, North China Plain, in 2015 and $2016\left(34^{\circ} 08^{\prime} 25^{\prime \prime} \mathrm{N}, 113^{\circ} 59^{\prime} 04^{\prime \prime} \mathrm{E}\right.$, a.s.l. $\left.71 \mathrm{~m}\right)$ (Figure 2). Four sets of large-scale weighing lysimeters $(2.0 \mathrm{~m}$ wide $\times 2.4 \mathrm{~m}$ long $\times 2.3 \mathrm{~m}$ in depth) along with four Insentek sensors were adopted to compare daily $\mathrm{ET}_{\mathrm{c}}$. The place had a continent temperate monsoon climate. The soil was a fluvo-aquic soil. Soil characteristics of the lysimeters are presented in Table 2. The bottom $30 \mathrm{~cm}$ was filled with a very coarse sand and $<3 \mathrm{~cm}$ gravels to permit drainage towards lysimeter outlet.

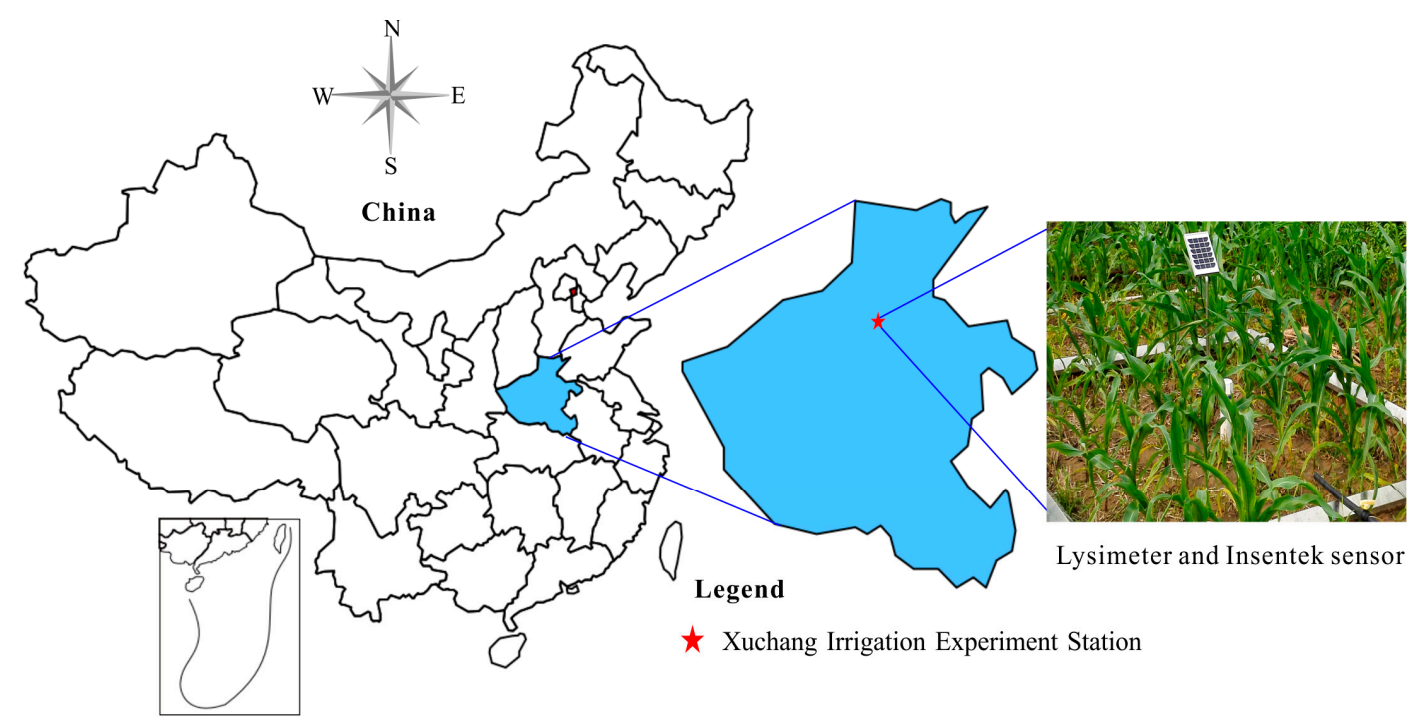

Figure 2. Schematic location of the Xuchang Irrigation Experiment Station and the lysimeter and Insentek sensor at the Station. 
Table 2. Soil physical properties prior to the start of the experiment at the Xuchang experiment station, North China Plain, in 2015.

\begin{tabular}{cccccccc}
\hline $\begin{array}{c}\text { Soil Layers } \\
(\mathbf{c m})\end{array}$ & $\begin{array}{c}\text { Clay } \\
(<\mathbf{0 . 0 0 2} \mathbf{~ m m})\end{array}$ & $\begin{array}{c}\text { Silt } \\
\mathbf{( 0 . 0 0 2}-\mathbf{0 . 0 5} \mathbf{~ m m})\end{array}$ & $\begin{array}{c}\text { Sand } \\
(\mathbf{0 . 0 5} \mathbf{~ m m})\end{array}$ & Soil Texture $\mathbf{1}^{\mathbf{1}}$ & $\begin{array}{c}\text { Wilting } \\
\text { Point }\end{array}$ & $\begin{array}{c}\text { Field } \\
\text { Capacity }\end{array}$ & $\begin{array}{c}\text { Soil Bulk } \\
\text { Density }\end{array}$ \\
\hline $0-30$ & $22 \%$ & $36 \%$ & $42 \%$ & Silt loam & 13.4 & 27.3 & 1.43 \\
$30-60$ & $24 \%$ & $39 \%$ & $37 \%$ & Silt loam & 12.5 & 25.8 & 1.46 \\
$60-100$ & $20 \%$ & $41 \%$ & $39 \%$ & Silt loam & 12.2 & 26.9 & 1.43 \\
$100-150$ & $15 \%$ & $32 \%$ & $53 \%$ & Sandy loam & 10.4 & 24.1 & 1.54 \\
$150-200$ & $10 \%$ & $22 \%$ & $68 \%$ & Sandy loam & 9.4 & 22.9 & 1.51 \\
\hline \multicolumn{7}{c}{}
\end{tabular}

Mean annual precipitation is $640.9 \mathrm{~mm}$, of which $65 \%$ falls during the maize growing season. Mean annual temperature is $14.7^{\circ} \mathrm{C}$, and annual sunshine hours are $2280 \mathrm{~h}$ [4]. Soil bulk density at the 0-60 $\mathrm{cm}$ soil layer was $1.45 \mathrm{~g} \cdot \mathrm{cm}^{-3}$ and soil organic matter at the same layer was $16.5 \mathrm{~g} \cdot \mathrm{kg}^{-1}$. Available $\mathrm{N}, \mathrm{P}_{2} \mathrm{O}_{5}$, and $\mathrm{K}_{2} \mathrm{O}$ at the same layer were $36.5,23.4$, and $219.8 \mathrm{mg} \cdot \mathrm{kg}^{-1}$, respectively [25]. The water table was detected more than $5 \mathrm{~m}$ below the soil surface.

\subsection{Experimental Design}

Crops were grown in a winter wheat (Triticum aestivum L.)-summer maize (Zea mays L.) relay cropping system. The lysimeters were made of steel metal sheets. Total lysimeter weight was approximately $24 \mathrm{t}$, including the container mass. The lysimeter was built in 2012, and $\mathrm{ET}_{\mathrm{c}}$ data have been monitored since March, 2014. Insentek sensors were installed at the center of each lysimeter in October, 2014. After three years of natural packing, the lysimeter monolith was regarded to duplicate the natural soil status [26].

The upper $2.0 \mathrm{~m}$ depth of soil monolith in each lysimeter was filled with undisturbed monolith. The large-scale weighing lysimeter system contains a main body, load cell, and data logger system (Figure 1). Weighing resolution was $\pm 100 \mathrm{~g}$, equal to $\pm 0.1 \mathrm{~mm}$ of water column. The masses of the lysimeters were measured every $30 \mathrm{~s}$, and the data were reported as $30 \mathrm{~min}$ means. The depth of lysimeter $(2.3 \mathrm{~m})$ permits development of normal rooting and water extraction for summer maize in the NCP [27]. Collecting buckets were suspended from the bottom of lysimeters to hold gravity drainage effluent. Load cells connected to the bucks were adopted to separately measure drainage mass without varying total weight of the lysimeters. Insentek sensors were installed between maize rows at the center of lysimeters. Insentek $\mathrm{ET}_{\mathrm{c}}$ was computed using water balance equation at daily interval. Lysimetric data are usually noisy due to wind and other external disturbance. The lysimeter noise was separated from signals using a filtering routine [28]. Additionally, biases on lysimeters were controlled by careful management of sowing, fertilization and irrigation.

A popular form of maize seeds (cultivar Pioneer 335) was sown on 5 June 2015 and 7 June 2016 (Figure 3). Maize was planted in a row with a spacing of $50 \mathrm{~cm}$ and plant-to-plant with a spacing of $30 \mathrm{~cm}$. After maize plants were thinned, there were 32 plants left per lysimeter, equal to a density of 66,700 plant ha ${ }^{-1}$. Application rates of fertilizer for each lysimeter were $225 \mathrm{~kg} \cdot \mathrm{ha}^{-1} \mathrm{~N}$, $180 \mathrm{~kg} \cdot \mathrm{ha}^{-1} \mathrm{P}_{2} \mathrm{O}_{5}$, and $55 \mathrm{~kg} \cdot \mathrm{ha}^{-1} \mathrm{~K}_{2} \mathrm{O}$, respectively. Diammonium phosphate and potassium sulfate were broadcast as base fertilizer prior to planting. One half amount of urea was applied as base fertilizer before sowing, whereas the rest amount of nitrogen was top-dressed at VT (tasseling) stage. Fertilizer was incorporated into soils to a depth of $20 \mathrm{~cm}$ using hand-cultural method. Besides a flood irrigation $(55 \mathrm{~mm})$ after maize sowing to guarantee seed germination, no supplemental irrigation was added as rainfall met the crop water requirement in both years. Weeds and pests control was applied according to the local governmental recommendations. 


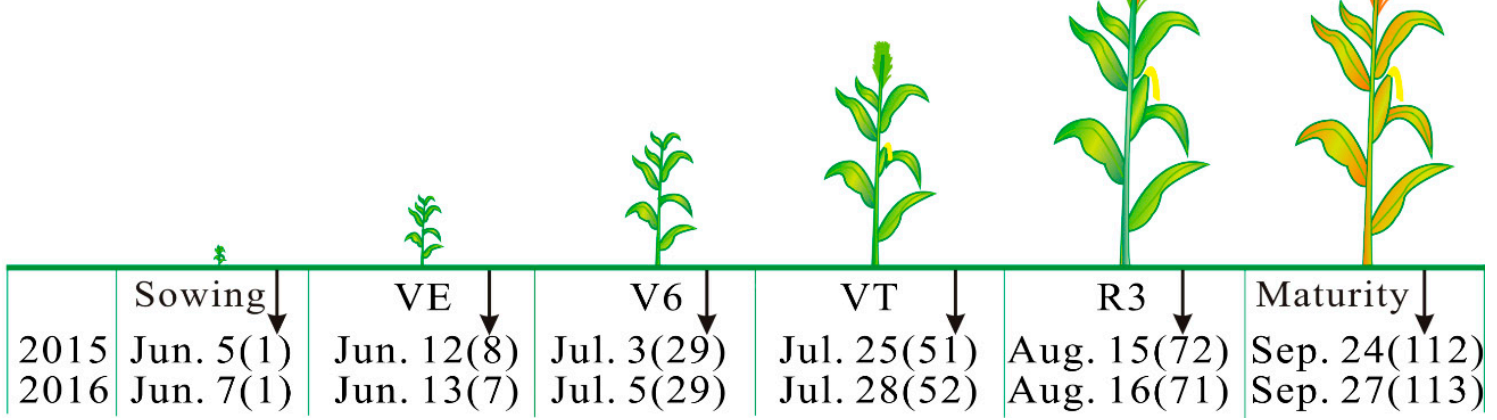

Figure 3. Seasonal schedule of crop growth stages of summer maize (VE, emergence; V(n), (n)-leaf stage; VT, tasseling stage; R3, milk stage) at the Xuchang Irrigation Experiment Station. The date in the figure was recorded when more than three quarters $(>75 \%)$ of the crops developed into the particular growth stage. The number in parentheses is days after sowing.

\subsection{Data Collection and Measurements}

\subsubsection{Soil Water Content}

Insentek sensors (Beijing Oriental Ecological Technology Ltd., Co., Beijing, China) were used to monitor soil water content $\left(\mathrm{SWC}, \mathrm{cm}^{3} \cdot \mathrm{cm}^{-3}\right.$ ) at $10 \mathrm{~cm}$ increment to a depth of $100 \mathrm{~cm}$. The radius of soil volume prospected by the Insentek sensors is $15 \mathrm{~cm}$ (Figure 1). The sensor is a wireless soil moisture sensor powered by a rechargeable battery, which was, in turn, charged by a solar panel. In order to evaluate the performance of Insentek sensors, relevant tests were conducted. Our experimental results showed that, compared to the oven-drying method, the Insentek sensor method is a promising tool for monitoring moisture across various soil textures.

\subsubsection{Daily Crop Evapotranspiration}

Daily lysimetric $\mathrm{ET}_{\mathrm{c}}$ was determined as the difference between the mass losses and gains on a whole day basis divided by the lysimeter area $\left(4.8 \mathrm{~m}^{2}\right)$, and the density of water $\left(1.0 \mathrm{~g} \cdot \mathrm{cm}^{-3}\right)$, converting lysimeter mass in $\mathrm{kg}$ to the equivalent depth of water in $\mathrm{mm}$. Daily $\mathrm{ET}_{\mathrm{c}}$ was calculated using Equation (1):

$$
\mathrm{ET}_{\mathrm{C}}=\Delta \mathrm{SWS}+\operatorname{Pre}+\mathrm{I}-\mathrm{R}-\mathrm{D}
$$

where $\Delta$ SWS is the daily changes in soil water storage $(\mathrm{mm})$ of lysimeter; Pre is the precipitation $(\mathrm{mm})$; I is the irrigation quota (mm); $R$ is the surface runoff, assumed to be negligible due to flat surface and lysimeter freeboard; and $\mathrm{D}$ is the drainage flux, measured by vacuum drainage systems.

Daily $\mathrm{ET}_{\mathrm{c}}$ estimated using Insentek sensors was calculated on a daily basis using the same water balance as in Equation (1), except the calculation of $\Delta$ SWS, which was calculated based on the soil volumetric water content in $0-100 \mathrm{~cm}$ depth.

\subsubsection{Grain Yield and Water Use Efficiency}

At physiological maturity, all maize plants from each lysimeter were sampled. To determine the grain yield, the ears of all plants of maize in each lysimeter were air dried until constant mass, and then the grain was separated, cleaned, and weighed. Grain yield was calculated on a dry-matter basis. Water use efficiency (WUE, $\mathrm{kg} \cdot \mathrm{ha}^{-1} \cdot \mathrm{mm}^{-1}$ ) was calculated as the grain yield $\left(\mathrm{kg} \cdot \mathrm{ha}^{-1}\right)$ produced per unit of $\mathrm{ET}_{\mathrm{c}}(\mathrm{mm})$.

\subsubsection{Relationship between $\mathrm{ET}_{\mathrm{c}}$ and Soil Water Content}

To determine the response of $\mathrm{ET}_{\mathrm{c}}$ to SWC on clear days, an exponential function combined with a quadratic function was used as follows: 


$$
\mathrm{ET}_{\mathrm{C}}=e^{a+b \times \mathrm{SWC}+c \times \mathrm{SWC}^{2}}
$$

where $\mathrm{ET}_{\mathrm{c}}$ is crop evapotranspiration $\left(\mathrm{mm} \cdot \mathrm{d}^{-1}\right)$ and SWC is soil water content $\left(\mathrm{cm}^{3} \cdot \mathrm{cm}^{-3}\right)$ on clear days; $a, b$, and $c$ are parameters to be fitted.

\subsubsection{Relationship between $\mathrm{ET}_{\mathrm{C}}$ and Precipitation}

Daily $\mathrm{ET}_{\mathrm{c}}$ on rainy days was restrained by precipitation, especially for moderate to heavy rain. In this study, $\mathrm{ET}_{\mathrm{C}}$ on rainy days was related to precipitation in a negative power function as follows:

$$
\mathrm{ET}_{\mathrm{c}}=a \times \operatorname{Pre}^{-b}
$$

where as $\mathrm{ET}_{\mathrm{c}}$ is crop evapotranspiration $\left(\mathrm{mm} \cdot \mathrm{d}^{-1}\right)$ on rainy days; Pre is precipitation $(\mathrm{mm}) ; a$ and $b$ are function parameters to be fitted.

\subsubsection{Meteorological Data}

A weather station was built adjacent to the lysimeter fields. The net radiation, air temperature, relative humidity, and wind speed and direction were recorded at $2.0 \mathrm{~m}$ height over mowed grass on an hourly basis.

\subsubsection{Evaluation of Insentek Data}

Performance of the Insentek sensor method to estimate daily $\mathrm{ET}_{\mathrm{c}}$ was evaluated using a combination of graphical and statistical methods. The evaluation factors include slope and intercept for linear regression between the lysimetric and Insentek data, coefficient of determination $\left(R^{2}\right)$, root mean square error (RMSE), and relative prediction deviation (RPD). The $\mathrm{R}^{2}$ describes the proportion of variance in lysimetric $\mathrm{ET}_{\mathrm{C}}$ explained by Insentek data. The RMSE can be used to investigate the differences between lysimetric and Insentek values. The RMSE is calculated using Equation (4):

$$
\mathrm{RMSE}=\sqrt{\sum_{i=1}^{n}\left(x_{\text {Insen }}-x_{\text {lysi }}\right)^{2} / n}
$$

where RMSE is the root mean square error; $x_{\text {Insen }}$ and $x_{l y s i}$ are corresponding ET $_{\mathrm{C}}$ values estimated based on Insentek and lysimetry, respectively; and $n$ is the number of values evaluated. The smaller the RMSE values are, the more accurate the Insentek data turn out to be.

The RPD is used to indicate the reliability of Insentek data. RPD is calculated using Equation (5):

$$
\operatorname{RPD}=\operatorname{STDEV}\left(x_{l y s i}\right) / \mathrm{RMSE}
$$

where RPD is the relative prediction deviation and STDEV is the standard deviation of lysimetric $\mathrm{ET}_{\mathrm{C}}$ values. $R P D \geq 2.0$ indicates Insentek data are reliable; $1.4<R P D<2.0$ means the data are feasible but need to be improved; and RPD $\leq 1.4$ indicates the data are unreliable [23].

\subsection{Statistical Analysis}

Data were analyzed using an analysis of variance with Statistical Analysis Software (version 19.0, SPSS Inc., Chicago, IL, USA). Significance was declared at the probability level of 0.05, unless

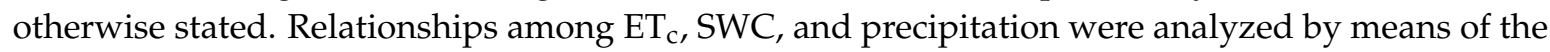
Levenberg-Marquardt Algorithm. Figures were plotted using Original Pro 9.1 (Origin Lab Corporation, Northampton, MA, USA). 


\section{Results}

\subsection{Dynamics of Insentek Soil Moisture}

Soil water content (SWC), monitored by Insentek sensors, was between 10.6 and $37.2 \mathrm{~cm}^{3} \cdot \mathrm{cm}^{-3}$ in 0-30 $\mathrm{cm}$ depth, 23.4 and $38.4 \mathrm{~cm}^{3} \cdot \mathrm{cm}^{-3}$ in 30-60 $\mathrm{cm}$ depth, and 27.3 and $38.8 \mathrm{~cm}^{3} \cdot \mathrm{cm}^{-3}$ in $60-100 \mathrm{~cm}$ depth in both seasons (Figure 4). Precipitation mainly increased SWC for 0-60 cm depth. On average, SWC increased by 33\%,11\%, 10\%, 8\%, 5\%, and 4\% for 0-10 cm, 10-20 cm, 20-30 cm, 30-40 cm, 40-50 cm, and 50-60 cm soil depths, respectively, by precipitation $>15 \mathrm{~mm}$. A limited effect on SWC was observed in 60-80 cm depth and minor effect in 80-100 cm depth. Except early vegetative phase before days after sowing (DAS) 40 (mid of July), a precipitation affect for SWC was discovered when soil depth was below $80 \mathrm{~cm}$. In the rooted soil layers $(0-60 \mathrm{~cm})$, SWC gradually declined from DAS 40 to maturity, whereas in $60 \mathrm{~cm}$ below soil layers, it remained stable, indicating the major depth of soil water extraction for lysimeter maize might be $60 \mathrm{~cm}$.
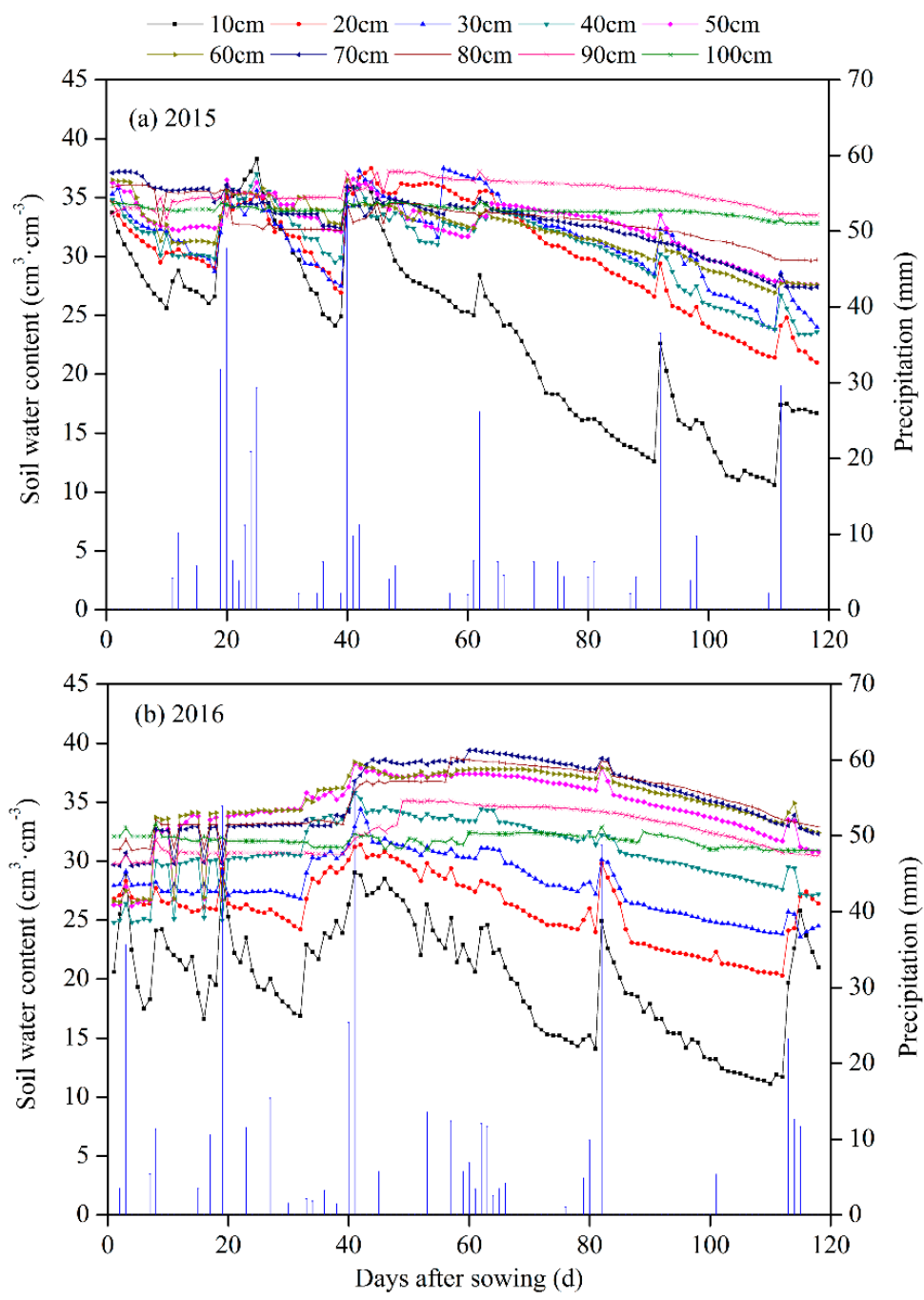

Figure 4. Seasonal variations in soil water content $\left(\mathrm{cm}^{3} \cdot \mathrm{cm}^{-3}\right)$ at $10 \mathrm{~cm}$ interval to a depth of $100 \mathrm{~cm}$ measured by Insentek sensors during maize growing seasons of (a) 2015 and (b) 2016. Vertical drop lines represent daily precipitation.

\subsection{Daily Crop Evapotranspiration}

Precipitation was 4\% and 6\% above normal in the maize growing seasons of 2015 and 2016. No supplemental irrigation was added after maize emergence (VE); thus, soil moisture was mainly affected 
by precipitation and $\mathrm{ET}_{\mathrm{c}}$. Lysimeter and Insentek produced similar trends in daily $\mathrm{ET}_{\mathrm{c}}$ (Figure 5). Lower $\mathrm{ET}_{\mathrm{c}}$ rates were observed when precipitation $>15 \mathrm{~mm}$. However, $\mathrm{ET}_{\mathrm{c}}$ increased markedly after precipitation occurrence due to an increase in soil water evaporation. On average, peak $\mathrm{ET}_{\mathrm{c}}$ rates, usually occurring in intermittent periods of precipitation, exceeded 2.5 and $4.5 \mathrm{~mm} \cdot \mathrm{d}^{-1}$ over vegetative and reproductive phases of maize. However, mean peak lysimetric $\mathrm{ET}_{\mathrm{C}}$ rates were $29 \%$ higher than Insentek $\mathrm{ET}_{\mathrm{C}}\left(4.87 \mathrm{vs} .3 .83 \mathrm{~mm} \cdot \mathrm{d}^{-1}\right)$ in both growing seasons. The highest $\mathrm{ET}_{\mathrm{c}}$ rates occurred on days after sowing (DAS) 53 (VT) in 2015, and on DAS 43 (V12) in 2016, respectively. Daily ET decreased appreciably and was kept to a relatively lower level until maturity. Throughout the seasons, variations in daily lysimetric and Insentek $\mathrm{ET}_{\mathrm{c}}$ basically changed with dynamics of daily mean temperature, except the period from DAS 55 (VT) to DAS 85 (R4) in 2016 with ongoing overcast and rain, giving rise to lower $\mathrm{ET}_{\mathrm{C}}$ than was expected.
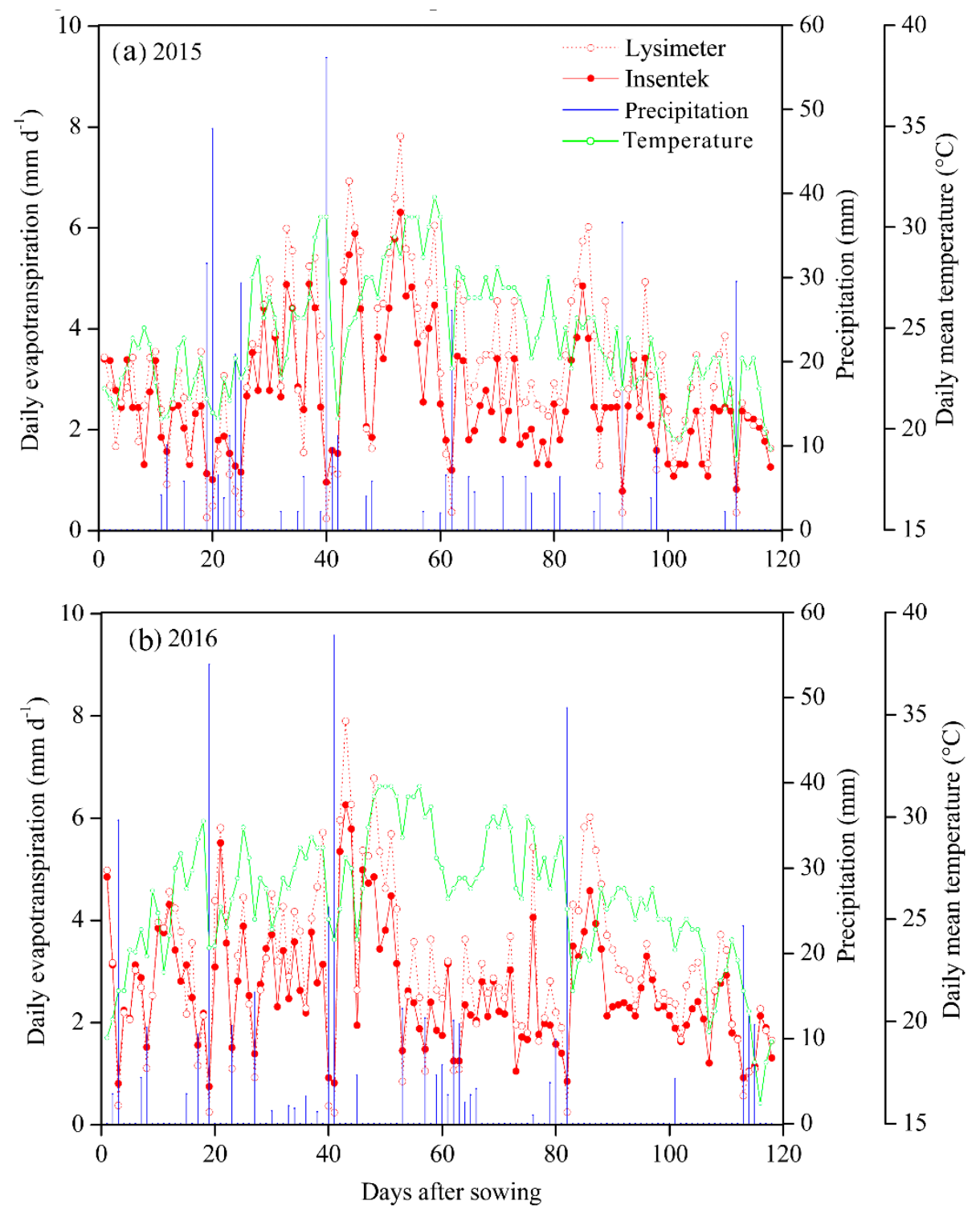

Figure 5. Daily evapotranspiration, air temperature, and precipitation during maize growing seasons of (a) 2015 and (b) 2016, at the Xuchang Irrigation Experiment Station, in the North China Plain. Vertical drop lines represent precipitation and solid green lines stand for temperature.

\subsection{Cumulative Crop Evapotranspiration}

On average, cumulative Insentek $\mathrm{ET}_{\mathrm{c}}$ was $310 \mathrm{~mm}$ with an average of $2.63 \mathrm{~mm} \cdot \mathrm{d}^{-1}$ in both years (Figure 6). Lysimeter produced 19\% higher cumulative $\mathrm{ET}_{\mathrm{c}}$ than did Insentek. Cumulative 
lysimetric $\mathrm{ET}_{\mathrm{c}}$ became constantly higher after DAS 40 (V10), and the discrepancies between them gradually grew from then on. Cumulative $\mathrm{ET}_{\mathrm{c}}$ increased with the accumulation of air temperature in a positive linear relationship. Lysimetric $\mathrm{ET}_{\mathrm{C}}$ showed a rapid response to precipitation with an average increase in $\mathrm{ET}_{\mathrm{c}}$ from 0.24 to $7.42 \mathrm{~mm} \cdot \mathrm{d}^{-1}$ during the following 5 days after heavy rainfall $(>50 \mathrm{~mm})$, whereas the response of Insentek $\mathrm{ET}_{\mathrm{c}}$ lagged behind lysimetric $\mathrm{ET}_{\mathrm{c}}$, with a smaller increase from 0.89 to $5.87 \mathrm{~mm} \cdot \mathrm{d}^{-1}$.
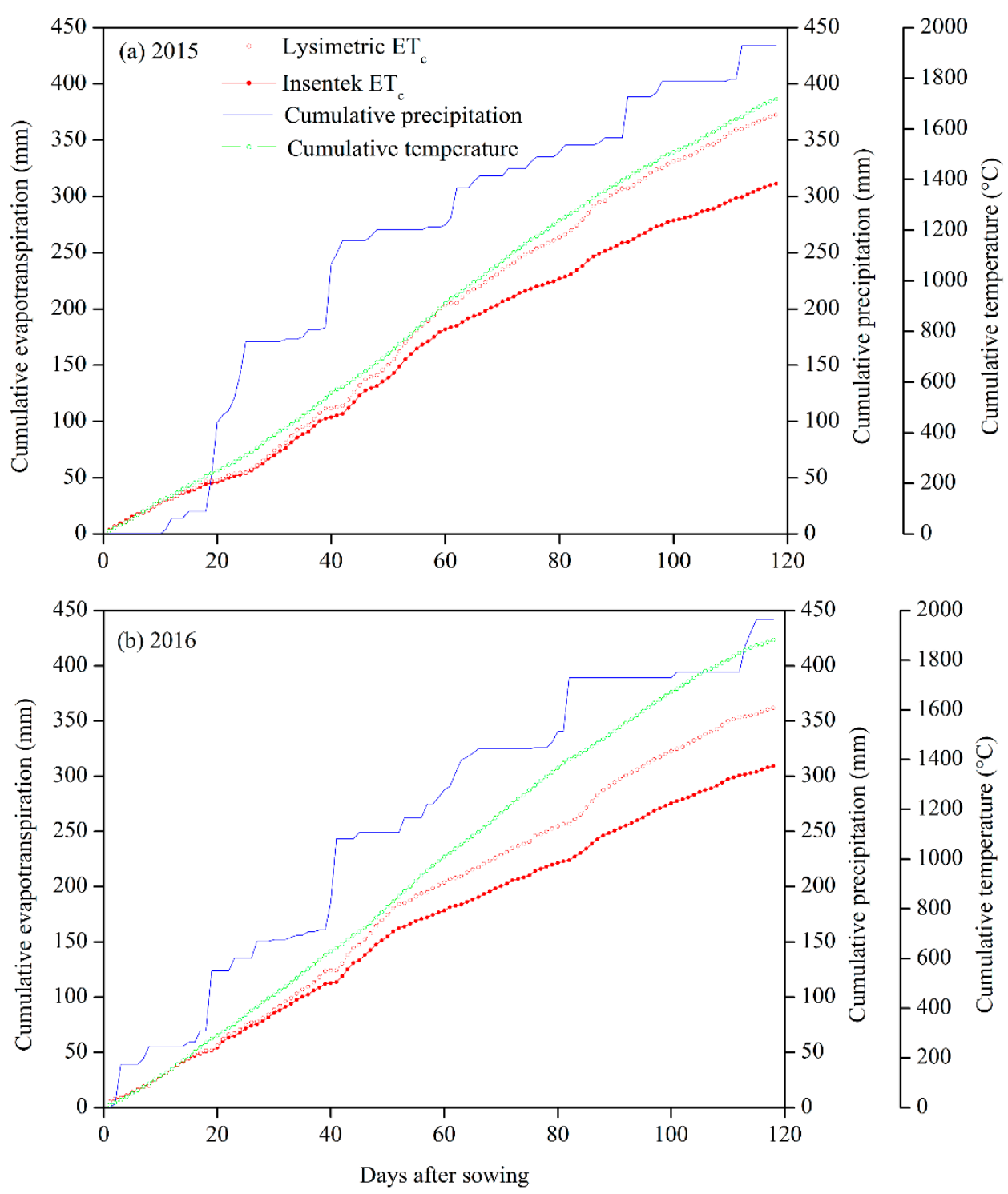

Figure 6. Cumulative evapotranspiration, cumulative air temperature, and precipitation during maize growing seasons of (a) 2015 and (b) 2016, at the Xuchang Irrigation Experiment Station, in the North China Plain.

\subsection{Responses of $E T_{c}$ to Soil Water Content}

As precipitation $>15 \mathrm{~mm}$ noticeably reduced $\mathrm{ET}_{\mathrm{C}}$, and increased $\mathrm{SWC}$, only data collected on clear days were selected for correlation analysis between $\mathrm{ET}_{\mathrm{C}}$ and $\mathrm{SWC}$. Our results showed that, over the two years, $\mathrm{ET}_{\mathrm{C}}$ was significantly correlated with SWC in 0-30 cm depth; however, it was not correlated with the SWC below $30 \mathrm{~cm}$ depth (Table 3). A detailed study showed that $\mathrm{ET}_{\mathrm{c}}$ increased with SWC in 0-30 cm depth in an exponential function combined with a quadratic function (Figure 7). Effects of SWC at $10 \mathrm{~cm}$ interval to $30 \mathrm{~cm}$ depth accounted for $32-59 \%\left(\mathrm{R}^{2}\right)$ of $\mathrm{ET}_{\mathrm{c}}$ variations, and the contributions of SWC to $\mathrm{ET}_{\mathrm{c}}$ declined from 10 to $30 \mathrm{~cm}$ soil layer. 
Table 3. Correlation coefficient $(\mathrm{R})$ of evapotranspiration $\left(\mathrm{ET}_{\mathrm{C}}\right)$ related to soil water content at each soil depth.

\begin{tabular}{ccccccccccc}
\hline Soil Depth $\mathbf{( c m )}$ & $\mathbf{1 0}$ & $\mathbf{2 0}$ & $\mathbf{3 0}$ & $\mathbf{4 0}$ & $\mathbf{5 0}$ & $\mathbf{6 0}$ & $\mathbf{7 0}$ & $\mathbf{8 0}$ & $\mathbf{9 0}$ & $\mathbf{1 0 0}$ \\
\hline Lysimetry & $0.67^{* *}$ & $0.57^{* *}$ & $0.53^{* *}$ & 0.21 & 0.19 & 0.17 & 0.12 & 0.09 & -0.04 & -0.12 \\
Insentek & $0.68^{* *}$ & $0.58^{* *}$ & $0.52^{* *}$ & 0.22 & 0.21 & 0.05 & 0.01 & -0.11 & -0.17 & -0.05 \\
\hline \multicolumn{8}{c}{ refers to significant correlation at $p<0.01}$.
\end{tabular}
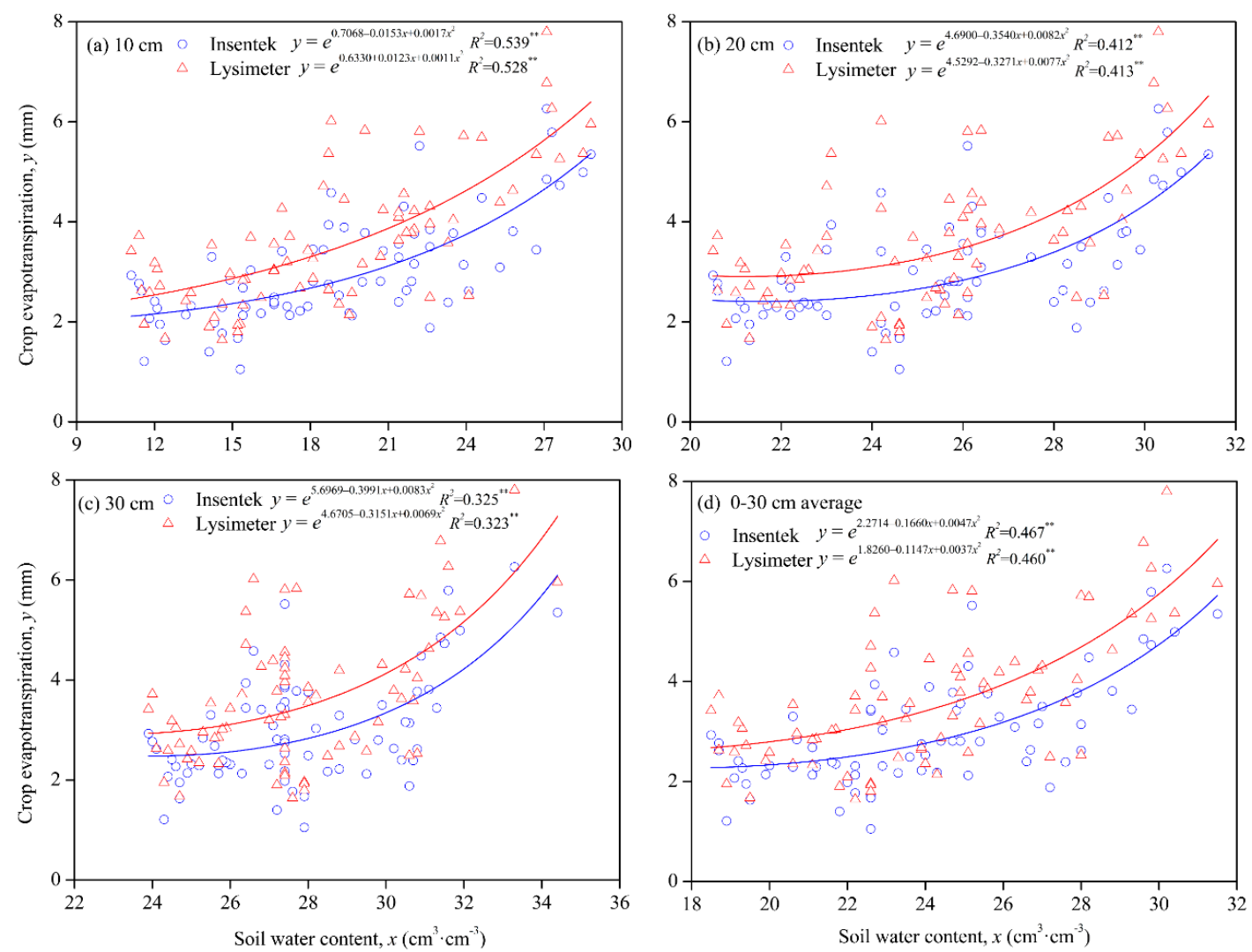

Figure 7. Relationships between crop evapotranspiration $\left(\mathrm{ET}_{\mathrm{c}}, \mathrm{mm}\right)$ and soil water content (SWC, $\mathrm{cm}^{3} \cdot \mathrm{cm}^{-3}$ ) on clear days at $10 \mathrm{~cm}$ interval to a depth of $30 \mathrm{~cm}$. (a) $\mathrm{ET}_{\mathrm{C}}$ related to $10 \mathrm{~cm} \mathrm{SWC;} \mathrm{(b)} \mathrm{ET}_{\mathrm{C}}$ related to $20 \mathrm{~cm} \mathrm{SWC;} \mathrm{(c)} \mathrm{ET}_{\mathrm{C}}$ related to $30 \mathrm{~cm} \mathrm{SWC;} \mathrm{(d)} \mathrm{ET}_{\mathrm{C}}$ related to $0-30$ average $\mathrm{SWC}$.

\subsection{Responses of $E T_{c}$ to Precipitation}

Both Insentek and lysimetric $\mathrm{ET}_{\mathrm{c}}$ was significantly reduced on rainy days. Our results showed that precipitation explained $84-87 \%$ variations of daily $\mathrm{ET}_{\mathrm{c}}$ on rainy days (Figure $8 \mathrm{a}$ ). Moreover, precipitation, as an independent factor controlling $\mathrm{ET}_{\mathrm{c}}$ when it rains, reduced daily $\mathrm{ET}_{\mathrm{c}}$ in a negative power function. Compared to $\mathrm{ET}_{\mathrm{c}}$ on clear days, precipitation averagely reduced lysimetric $\mathrm{ET}_{\mathrm{c}}$ by $72 \%$, and Insentek $\mathrm{ET}_{\mathrm{c}}$ by $54 \%$, indicating a faster response of lysimetric $\mathrm{ET}_{\mathrm{c}}$ to precipitation than Insentek $\mathrm{ET}_{\mathrm{c}}$.

\subsection{Goodness of Fit}

There exists a significant positive linear correlation between Insentek and lysimetric $\mathrm{ET}_{\mathrm{c}}$ data, with a slope of $0.68-0.69$, and an intercept of $0.48-0.51$, taking Insentek $\mathrm{ET}_{\mathrm{c}}$ as $y$ values (Figure $8 \mathrm{~b}$ ). A test for goodness of fit showed that the RMSE values were less than $0.87 \mathrm{~mm}$, and RPD values were around 2.0, indicating the Insentek sensors method is, to some extent, reliable for predicting real $\mathrm{ET}_{\mathrm{C}}$ of summer maize in the NCP (Table 4). Slopes smaller than 1.0 indicated that Insentek $\mathrm{ET}_{\mathrm{c}}$ was generally smaller than lysimetric $\mathrm{ET}_{\mathrm{c}}$, though they have similar $\mathrm{ET}_{\mathrm{C}}$ trends. Thus, improvements should be 
considered to enhance Insentek sensors accuracy. Those measures include, but are not limited to, using longer Insentek sensors (e.g., $200 \mathrm{~cm}$ long) to represent SWC dynamics in deeper layers.
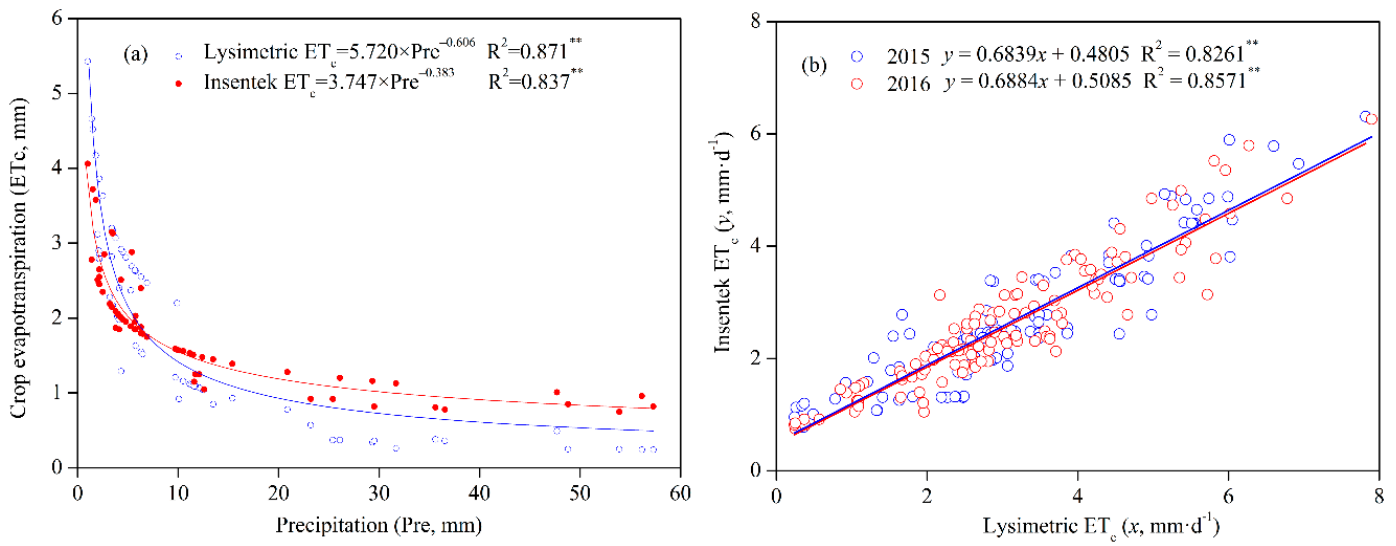

Figure 8. (a) Relationships between crop evapotranspiration $\left(\mathrm{ET}_{\mathrm{C}}, \mathrm{mm}\right)$ and precipitation (Pre, $\mathrm{mm}$ ) on rainy days fitted to a negative power function. (b) Linear regression between Insentek $\mathrm{ET}_{\mathrm{C}}$ and lysimetric $\mathrm{ET}_{\mathrm{C}}$.

Table 4. Test for linear regression and goodness of fit between Insentek $\operatorname{ET}_{\mathrm{C}}(y)$ and lysimetric $\operatorname{ET}_{\mathrm{c}}(x)$ data of summer maize in 2015 and 2016.

\begin{tabular}{ccccccc}
\hline \multirow{2}{*}{ Year } & \multicolumn{3}{c}{ Linear Correlation } & \multicolumn{2}{c}{ Goodness of Fit } & Significance \\
\cline { 2 - 7 } & Slope & Intercept & $\mathbf{R}^{\mathbf{2}}$ & RMSE & RPD & $p$ \\
\hline 2015 & 0.6839 & 0.4805 & 0.8261 & 0.872 & 1.921 & 0.001 \\
2016 & 0.6884 & 0.5085 & 0.8571 & 0.776 & 2.061 & 0.001 \\
\hline
\end{tabular}

$\mathrm{R}^{2}$ is coefficient of determination; RMSE is root mean square error used to evaluate the differences between estimated and observed $\mathrm{ET}_{\mathrm{c}}$; RPD is relative prediction deviation, values measured by Insentek sensor are reliable with $\mathrm{RPD} \geq 2.0$ [23]; $p$ is probability.

\subsection{Grain Yield and Water Use Efficiency}

In the NCP, maize is usually planted after the harvest of wheat in a winter wheat-summer maize double-cropping system. Due to soil water extraction by wheat and scarcity of rainfall, initial soil water storage $\left(\mathrm{SWS}_{0}\right)$ prior to maize sowing was extremely low (Table 5). This necessitated an irrigation immediately after sowing to guarantee seed germination. Grain yields were on average $15 \%$ lower than the yield (9165 $\mathrm{kg} \cdot \mathrm{ha}^{-1}$ ) from surrounding field experiment, probably due to soil compaction and saline stress in a lysimetric environment. Because the Insentek sensor stood for $100 \mathrm{~cm}$ soil depth, whereas lysimeter for $200 \mathrm{~cm}$, as well as lower SWC in upper layers, the Insentek SWS 0 was extremely lower in 2015 and 2016. At harvest, lysimetric $\mathrm{SWS}_{\mathrm{h}}$ was 19\% and 17\% higher than Insentek $\mathrm{SWS}_{\mathrm{h}}$. Consequently, lysimetry reported a $20 \%$ and $17 \%$ higher $\mathrm{ET}_{\mathrm{c}}$ in 2015 and 2016 , resulting in a $16 \%$ and $14 \%$ lower WUE than the Insentek method.

Table 5. Grain yield and estimated soil water storage, crop evapotranspiration, and water use efficiency using the Insentek and lysimetric methods, at the Xuchang Irrigation Experiment Station in 2015 and 2016.

\begin{tabular}{|c|c|c|c|c|c|c|c|c|}
\hline Year & Treatment & $\begin{array}{c}\text { Irrigation } \\
(\mathrm{mm})\end{array}$ & $\begin{array}{l}\text { Precipitation } \\
(\mathrm{mm})\end{array}$ & $\begin{array}{c}\text { Grain Yield } \\
\left(\mathrm{kg} \cdot \mathrm{ha}^{-1}\right)\end{array}$ & $\begin{array}{l}\mathrm{SWS}_{0}{ }^{1} \\
(\mathrm{~mm})\end{array}$ & $\begin{array}{c}\mathrm{SWS}_{\mathrm{h}}{ }^{1} \\
(\mathrm{~mm})\end{array}$ & $\begin{array}{c}\mathrm{ET}_{\mathrm{c}} \\
(\mathrm{mm})\end{array}$ & $\begin{array}{c}\text { WUE }^{3} \\
\left(\mathrm{~kg} \cdot \mathrm{ha}^{-1} \cdot \mathrm{mm}^{-1}\right)\end{array}$ \\
\hline \multirow{2}{*}{2015} & Insentek & \multirow{2}{*}{55} & \multirow{2}{*}{434} & \multirow{2}{*}{7919} & $86 b^{2}$ & $264 \mathrm{~b}$ & $311 \mathrm{~b}$ & $25.4 \mathrm{a}$ \\
\hline & Lysimeter & & & & 197 a & $314 \mathrm{a}$ & $372 \mathrm{a}$ & $21.3 \mathrm{~b}$ \\
\hline \multirow{2}{*}{2016} & Insentek & \multirow{2}{*}{55} & \multirow{2}{*}{442} & \multirow{2}{*}{7670} & $101 \mathrm{~b}$ & $289 \mathrm{~b}$ & $309 \mathrm{~b}$ & $24.8 \mathrm{a}$ \\
\hline & Lysimeter & & & & $203 a$ & $338 \mathrm{a}$ & $362 \mathrm{a}$ & $21.2 \mathrm{~b}$ \\
\hline
\end{tabular}

${ }^{1} \mathrm{SWS}_{0}$ and $\mathrm{SWS}_{\mathrm{h}}$ is soil water storage prior to sowing and after harvest of maize, respectively, as estimated by the Insentek and lysimetric method; ${ }^{2}$ Different letters stand for significant differences at $p<0.05 ;{ }^{3}$ WUE is water use efficiency. 


\section{Discussion}

\subsection{Advantage and Disadvantage of Lysimetry and Insentek Method}

The Insentek sensor method had several advantages over the lysimetry method, including ease of deployment, lower initial expense, and wireless transmission of real-time data [4,25]. In this study, Insentek sensors were installed inside lysimeter soils, allowing to record daily dynamics of SWC to a depth of $100 \mathrm{~cm}$. Previous studies indicated SWC measurement depth for $\mathrm{ET}_{\mathrm{c}}$ estimation should extend to the major depth of soil water extraction, which was flexible with crop types and weather conditions [11,29]. In Bushland, Texas, in a semiarid climate, it was found that $100 \mathrm{~cm}$ long neutron probe access tubes were sufficient to represent lysimetric $\mathrm{ET}_{\mathrm{C}}$ on an irrigated cotton field $[18,19]$. In this study, maize plants were grown under a semi-humid climate with seasonal precipitation $\geq 450 \mathrm{~mm}$. Initially, the SWC in the upper layers was extremely low at maize sowing, giving rise to discrepancy between Insentek and lysimetric $\mathrm{ET}_{\mathfrak{c}}$, which was calculated based on different depths. This was probably attributable to the water uptake depth for wheat exceeding $100 \mathrm{~cm}$ under traditional border irrigation, and low water availability at wheat harvest in the NCP [30,31]. Maize crops usually have a shallower rooting system due to the high frequency of precipitation [32,33]. Nevertheless, according to soil water depletion depth monitored by Insentek sensors, the major depth of water extraction of maize on lysimeters might be $60 \mathrm{~cm}$. Therefore, $\mathrm{ET}_{\mathrm{c}}$ rates simulated by a $100 \mathrm{~cm}$ long Insentek sensor can be assumed as representative of actual rates. Additionally, compared with the eddy covariance and remote sensing methods, $\mathrm{ET}_{\mathrm{c}}$ estimates by a network of soil moisture sensors were considered as viable source of ground truth $\mathrm{ET}_{\mathrm{c}}$ data that were convincing both in theory and practice [34]. Previous studies have shown that $\mathrm{ET}_{\mathrm{C}}$ determined by the neutron probe method can represent lysimetric $\mathrm{ET}_{\mathrm{C}}$, however, it wasn't able to calculate $\mathrm{ET}_{\mathrm{c}}$ on a daily or sub-daily scale due to a lack of automatic measurement $[35,36]$. This shortcoming can be overcome by Insentek sensors.

However, there still exist limitations for Insentek sensors to simulate $\mathrm{ET}_{\mathrm{c}}$. For example, the Insentek method led to weaker $\mathrm{ET}_{\mathrm{c}}$ responses to precipitation compared to the lysimetry method [25]. This led to a bias in $\mathrm{ET}_{\mathrm{c}}$ simulation on rainy days. Nevertheless, Insentek method had merits to reduce potential $\mathrm{ET}_{\mathrm{c}}$ errors induced by animal invasion and other disturbance factors. Although response of Insentek $\mathrm{ET}_{\mathrm{c}}$ to precipitation lagged behind lysimetry, it increased stability of $\mathrm{ET}_{\mathrm{C}}$ estimation due to a good performance in keeping out outside disturbance factors.

\subsection{Cumulative Evapotranspiration Responses to Soil Water Content}

Cumulative $\mathrm{ET}_{\mathrm{c}}$ varied from 309 to $372 \mathrm{~mm}$ for summer maize in 2015 and 2016. The values were consistent with previous $\mathrm{ET}_{\mathrm{C}}$ total for summer maize in the NCP [37], but were up to $50 \%$ lower than that of irrigated spring maize in semi-arid region of northern China [38]. Additionally, the values were up to $100 \%$ lower than reported for the southern High Plains in the USA [3]. The lower $\mathrm{ET}_{\mathrm{c}}$ rates could be attributed to short growth duration ( $<90$ days) and the almost rain-fed condition for summer maize in the NCP. In this study, water extraction depth mainly concentrated on 0-60 cm soil layer. This was probably due to favorable climate conditions such as adequate precipitation. Our study showed that daily $\mathrm{ET}_{\mathrm{c}}$ had a positive exponential relationship with soil moisture in topsoil $(0-30 \mathrm{~cm})$. One of the reasons might be that the largest variations in soil moisture occurred in topsoil because the shallow zone had the largest root density and water extraction by maize plants [19]. Some used neutron probe method to estimate $\mathrm{ET}_{\mathrm{c}}$ variations on a weekly basis; however, the Insentek sensor method had advances in automatic records of SWC, and was safe from radiation. Significant correlation between $E_{C}$ and near surface SWC can be verified by the finding that only SWC in the upper $30 \mathrm{~cm}$ of soil significantly varied in irrigated cotton fields at Bushland, Texas [39].

\subsection{Comparison of Insentek Method to Other Methods}

Although prior studies concluded that $\mathrm{ET}_{\mathrm{c}}$ based on a $100 \mathrm{~cm}$ deep access tube was sufficient to represent lysimeter $\mathrm{ET}_{\mathrm{c}}$ [40], there was still a $14 \%$ under-estimate of mean daily $\mathrm{ET}_{\mathrm{c}}$ by the Insentek 
sensor method compared to the lysimetry method in the present study. One probable approach to improve the accuracy of Insentek $\mathrm{ET}_{\mathrm{c}}$ was to adopt a $200 \mathrm{~cm}$ long probe equivalent to lysimeter depth, which will be conducted in further study. A comparison of $\mathrm{ET}_{\mathrm{c}}$ calculated using lysimetry and neutron probe method has been conducted [35]. Some concluded that there was no difference between them $[18,41,42]$, while others found that $\mathrm{ET}_{\mathrm{c}}$ from lysimeters was greater than that of the oven-drying or neutron probe method $[43,44]$. Using remotely sensed $\mathrm{ET}_{\mathrm{c}}$, it was found that the $\mathrm{ET}_{\mathrm{C}}$ produced differences of around $20-45 \%$ with the ground measurements using large aperture scintillometer systems during the growing season, and the model performance deteriorated for cloudy days [20]. Larger errors of daily $\mathrm{ET}_{\mathrm{c}}$ estimates were associated with clouds and rain events, which affected satellite normal mapping, adding additional data noise [45]. Compared with remote sensing methodology, the Insentek method produced smaller differences. Compared with soil coring and neutron probe methods, Insentek sensors recorded soil moisture hourly without labor cost, directly improving the convenience and efficiency of $\mathrm{ET}_{\mathrm{c}}$ estimation.

\subsection{Simulating Crop Evapotranspiration on Rainy Days}

Using a remote sensing $\mathrm{ET}_{\mathrm{c}}$ model, it was found that $\mathrm{ET}_{\mathrm{c}}$ had a negative correlation with precipitation in areas where the growing-season precipitation was $250 \mathrm{~mm}$ [21]. However, in arid areas with precipitation less than $200 \mathrm{~mm}$, the correlation becomes weaker due to insufficient precipitation and a more complex water-heat flux interaction [46]. It should be noticed that those correlations by remote sensing were calculated mostly on an annual basis [47]. It did not reflect the instantaneous response of $\mathrm{ET}_{\mathrm{C}}$ to daily precipitation as was done in this study. Through analysis, we found that precipitation with an amount $\geq 15 \mathrm{~mm}$ significantly inhibited daily $\mathrm{ET}_{\mathrm{c}}$. Thus, $\mathrm{ET}_{\mathrm{c}}$ data on rainy days were independently used to analyze the correlation. Our results showed that simulated $\mathrm{ET}_{\mathrm{c}}$ were in good agreement with the actual $\mathrm{ET}_{\mathrm{c}}$ on rainy days. Both lysimetric and Insentek $\mathrm{ET}_{\mathrm{c}}$ was related to precipitation in a negative power function. The effect of precipitation on Insentek $\mathrm{ET}_{\mathrm{c}}$ was smaller compared to lysimetric $\mathrm{ET}_{\mathrm{c}}$, indicating a weaker response to precipitation. A probable reason was that Insentek $\mathrm{ET}_{\mathrm{c}}$ was estimated using soil water storage changes after rain-water infiltration, which needed time to finish the process [4].

\section{Conclusions}

The North China Plain $(\mathrm{NCP})$ produces one third of China's maize production $(\approx 220$ million tons per year), and is one of the most productive granaries in China. In this work, an alternative based on Insentek soil moisture data to estimate $\mathrm{ET}_{\mathrm{C}}$ was evaluated in comparison with lysimetry in the NCP. Insentek $\mathrm{ET}_{\mathrm{C}}$ had a significant linear correlation $\left(\mathrm{R}^{2}=0.83-0.86\right)$ to lysimetric $\mathrm{ET}_{\mathrm{c}}$, with RMSE $<0.87 \mathrm{~mm}$, and RPD $<2.1$, indicating that Insentek sensors are efficient tools in estimating maize $\mathrm{ET}_{\mathrm{c}}$ in the NCP with acceptable accuracy. Since precipitation and SWC play an important role in water balance calculation for $\mathrm{ET}_{\mathrm{C}}$, responses of $\mathrm{ET}_{\mathrm{C}}$ to them were analyzed on different weather days. The results indicated that $\mathrm{ET}_{\mathrm{c}}$ significantly relates to precipitation (Pre) on rainy days in a power function $\left(\mathrm{R}^{2}=0.84-0.87\right)$. On clear days, $\mathrm{ET}_{\mathrm{C}}$ significantly relates to $\mathrm{SWC}$ in topsoil $(0-30 \mathrm{~cm})$ in an exponential function $\left(R^{2}=0.32-0.53\right)$. The combined SWC $(0-30 \mathrm{~cm})-P r e-\mathrm{ET}_{\mathrm{c}}$ model may offer significant potential for predicting $\mathrm{ET}_{\mathrm{c}}$. Our method provides a reference for reducing lysimetric data noise and may be useful to the study on responses of $\mathrm{ET}_{\mathrm{C}}$ to climatic change in the NCP.

Author Contributions: Conceptualization, A.Q. and J.X.; methodology, D.N.; software, Z.L.; validation, B.S., and B.Z.; formal analysis, A.Q.; investigation, D.N.; resources, A.D.; data curation, A.D.; writing-original draft preparation, A.Q.; writing-review and editing, D.N.

Funding: This research was funded by the National Key Research and Development Program (2017YFD0301102), the China Agriculture Research System (CARS-02), the Agricultural Science and Technology Innovation Program (ASTIP), and the Central Public-interest Scientific Institution Basal Research Fund (Farmland Irrigation Research Institute, CAAS, FIRI2017-04). 
Acknowledgments: The authors sincerely thank the three anonymous reviewers who made valuable comments on this paper.

Conflicts of Interest: The authors declare no conflict of interest. The founding sponsors had no role in the design of the study, in the collection, analyses, or interpretation of data.

\section{References}

1. Liu, S.; Mo, X.; Lin, Z.; Xu, Y.; Ji, J.; Gang, W.; Richey, J. Crop yield responses to climate change in the Huang-Huai-Hai Plain of China. Agric. Water Manag. 2010, 97, 1195-1209. [CrossRef]

2. Wang, X.; Ren, Y.; Zhang, S.; Chen, Y.; Wang, N. Applications of organic manure increased maize (Zea mays L.) yield and water productivity in a semi-arid region. Agric. Water Manag. 2017, 187, 88-98. [CrossRef]

3. Howell, T.; Evett, S.R.; Tolk, J.A.; Schneider, A.D.; Steiner, J.L. Evapotranspiration of corn, Southern High Plains. In Proceedings of the International Conference in Evapotranspiration and Irrigation Scheduling, San Antonio, TX, USA, 3-6 November 1996; pp. 158-165. [CrossRef]

4. Qin, A.; Ning, D.; Liu, Z.D.; Sun, B.; Zhao, B.; Xiao, J.; Liu, Z.G. Evaluating responses of crop water use, soil water storage and infiltration to precipitation using Insentek probes. In Proceedings of the 2018 International Conference on Mathematics, Modelling, Simulation and Algorithms, Chengdu, China, 25-26 March 2018; pp. 353-356. [CrossRef]

5. Liu, Z.D.; Qin, A.; Zhang, J.; Sun, J.; Ning, D.; Zhao, B.; Xiao, J.; Liu, Z.G.; Duan, A. Maize yield as a function of water availability across precipitation years in the North China Plain. Crop Sci. 2017, 57, 2226-2237. [CrossRef]

6. Liu, Z.; Qin, A.; Zhao, B.; Ataulkarim, S.T.; Xiao, J.; Sun, J.; Ning, D.; Liu, Z.; Nan, J.; Duan, A. Yield response of spring maize to inter-row subsoiling and soil water deficit in northern China. PLOS ONE 2016, 11, e0153809. [CrossRef]

7. Fang, Q.; Ma, L.; Green, T.; Yu, Q.; Wang, T.; Ahuja, L. Water resources and water use efficiency in the North China Plain: Current status and agronomic management options. Agric. Water Manag. 2010, 97, 1102-1116.

8. Rockström, J.; Barron, J. Water productivity in rainfed systems: Overview of challenges and analysis of opportunities in water scarcity prone savannahs. Irrig. Sci. 2007, 25, 299-311. [CrossRef]

9. Zhang, X.; Chen, S.; Pei, D.; Liu, M.; Sun, H. Improved water use efficiency associated with cultivars and agronomic management in the North China Plain. Agron. J. 2005, 97, 783-790. [CrossRef]

10. Marek, G.; Gowda, P.; Evett, S.; Baumhardt, R.; Brauer, D.; Howell, T.; Marek, T.; Srinivasan, R. Estimating evapotranspiration for dryland cropping systems in the semiarid Texas High Plains using SWAT. J. Am. Water Resour. Assoc. 2016, 52, 298-314. [CrossRef]

11. Evett, S.; Kustas, W.; Gowda, P.; Prueger, J.; Howell, T. Overview of the Bushland evapotranspiration and agricultural remote sensing experiment 2008 (BEAREX08): A field experiment evaluating methods quantifying ET at multiple scales. Adv. Water Resour. 2012, 50, 4-19. [CrossRef]

12. Zhang, X.; Chen, S.; Sun, H.; Wang, Y.; Shao, L. Water use efficiency and associated traits in winter wheat cultivars in the North China Plain. Agric. Water Manag. 2010, 97, 1117-1125. [CrossRef]

13. Ford, C.R.; Hubbard, R.M.; Kloeppel, B.D.; Vose, J.M. A comparison of sap flux-based evapotranspiration estimates with catchment-scale water balance. Agric. For. Meteorol. 2007, 145, 176-185. [CrossRef]

14. Zhang, B.; Kang, S.; Li, F.; Zhang, L. Comparison of three evapotranspiration models to Bowen ratio-energy balance method for a vineyard in an arid desert region of northwest China. Agric. For. Meteorol. 2008, 148, 1629-1640. [CrossRef]

15. Zhang, Z.; Tian, F.; Hu, H.; Yang, P. A comparison of methods for determining field evapotranspiration: Photosynthesis system, sap flow, and eddy covariance. Hydrol. Earth Syst. Sci. 2014, 18, 1053-1072. [CrossRef]

16. Lu, Y.; Ma, D.; Chen, X.; Zhang, J. A simple method for estimating field crop evapotranspiration from pot experiments. Water 2018, 10, 1823. [CrossRef]

17. Schneider, A.; Howell, T.; Moustafa, A.; Evett, S.; Abou-Zeid, W. A simplified weighing lysimeter for monolithic or reconstructed soils. Appl. Eng. Agric. 1998, 14, 267-273. [CrossRef]

18. Evett, S.; Schwartz, R.; Tolk, J.; Howell, T. Soil profile water content determination: Spatiotemporal variability of electromagnetic and neutron probe sensors in access tubes. Vadose Zone J. 2009, 8, 926-941. [CrossRef]

19. Evett, S.; Tolk, J.; Howell, T. A depth control stand for improved accuracy with the neutron probe. Vadose Zone J. 2003, 2, 642-649. [CrossRef] 
20. Song, L.; Liu, S.; Kustas, W.; Nieto, H.; Sun, L.; Xu, Z.; Skaggs, T.; Yang, Y.; Ma, M.; Xu, T.; et al. Monitoring and validating spatially and temporally continuous daily evaporation and transpiration at river basin scale. Remote Sens. Environ. 2018, 219, 72-88. [CrossRef]

21. Gu, C.; Ma, J.; Zhu, G.; Yang, H.; Zhang, K.; Wang, Y.; Gu, C. Partitioning evapotranspiration using an optimized satellite-based ET model across biomes. Agric. For. Meteorol. 2018, 259, 355-363. [CrossRef]

22. Elnmer, A.; Khadr, M.; Kanae, S.; Tawfik, A. Mapping daily and seasonally evapotranspiration using remote sensing techniques over the Nile delta. Agric. Water Manag. 2019, 213, 682-692. [CrossRef]

23. Chen, H.; Zhao, G.; Zhang, X.; Wang, R.; Sun, L.; Chen, J. Improving estimation precision of soil organic matter content by removing effect of soil moisture from hyperspectra. TCSAE 2014, 30, 91-100. [CrossRef]

24. National Standards of China (NSC). China Soil Classification and Code (GB/T 17296-2009); NSC: Beijing, China, 2009.

25. Qin, A.; Ning, D.; Liu, Z.; Zhao, B.; Liu, Z.; Duan, A.; Xiao, J. Simulating crop evapotranspiration using Insentek soil moisture for maize plants on lysimeters. In Proceedings of the 2018 International Conference on Modeling, Simulation and Analysis, Wuhan, China, 7-8 February 2018; pp. 311-315.

26. Hillel, D. Introduction to Environmental Soil Physics; Elsevier Academic Press: Amsterdam, The Netherlands, 2004.

27. Wu, Y.; Du, T.; Li, F.; Li, S.; Ding, R.; Tong, L. Quantification of maize water uptake from different layers and root zones under alternate furrow irrigation using stable oxygen isotope. Agric. Water Manag. 2016, 168, 35-44. [CrossRef]

28. Peters, A.; Nehls, T.; Schonsky, H.; Wessolek, G. Separating precipitation and evapotranspiration from noise-A new filter routine for high-resolution lysimeter data. Hydrol. Earth Syst. Sci. 2014, 18, 14645-14674. [CrossRef]

29. Maayar, M.; Price, D.; Chen, J. Simulating daily, monthly and annual water balances in a land surface model using alternative root water uptake schemes. Adv. Water Resour. 2009, 32, 1444-1459. [CrossRef]

30. Lv, G.; Kang, Y.; Lan, L.; Wan, S. Effect of irrigation method on root development and profile soil water uptake in winter wheat. Irrig. Sci. 2010, 28, 387-398. [CrossRef]

31. Liu, Z.D.; Qin, A.; Duan, A.; Zhang, J.; Sun, J.; Ning, D.; Zhao, B.; Mi, Z.; Liu, Z.G. Soil moisture and crop evapotranspiration forecast for winter wheat based on weather information in North China Plain. In Proceedings of the 2nd International Conference on Modelling, Simulation and Applied Mathematics, Bangkok, Thailand, 26-27 March 2017; pp. 295-299. [CrossRef]

32. Gaur, N.; Mohanty, B.P.; Kefauver, S.C. Effect of observation scale on remote sensing based estimates of evapotranspiration in a semi-arid row cropped orchard environment. Precis. Agric. 2017, 18, 762-778. [CrossRef]

33. Soylu, M.E.; Loheide, S.P.I.; Kucharik, C.J. Effects of root distribution and root water compensation on simulated water use in maize influenced by shallow groundwater. Vadose Zone J. 2017, 16, 1-15. [CrossRef]

34. Evett, S.; Schwartz, R.; Lascano, R.; Pelletier, M. In-soil and down-hole soil water sensors: Characteristics for irrigation management. In Proceedings of the 5th Decennial National Irrigation Symposium, Phoenix, AZ, USA, 5-8 December 2010.

35. Tolk, J.; Evett, S. Lysimetry versus neutron moisture meter for evapotranspiration determination in four soils. Soil Sci. Soc. Am. J. 2009, 73, 1693-1698. [CrossRef]

36. Oberholzer, S.; Prasuhn, V.; Hund, A. Crop water use under Swiss pedoclimatic conditions-Evaluation of lysimeter data covering a seven-year period. Field Crops Res. 2017, 211, 48-65. [CrossRef]

37. Zhang, X.; Chen, S.; Sun, H.; Shao, L.; Wang, Y. Changes in evapotranspiration over irrigated winter wheat and maize in North China Plain over three decades. Agric. Water Manag. 2011, 98, 1097-1104. [CrossRef]

38. Li, Y.; Cui, J.; Zhang, T.; Zhao, H. Measurement of evapotranspiration of irrigated spring wheat and maize in a semi-arid region of north China. Agric. Water Manag. 2003, 61, 1-12. [CrossRef]

39. Alfieri, J.; Kustas, W.; Prueger, J.; Hipps, L.; Evett, S.; Basara, J.; Neale, C.; French, A.; Colaizzi, P.; Agam, N.; et al. On the discrepancy between eddy covariance and lysimetry-based surface flux measurements under strongly advective conditions. Adv. Water Resour. 2012, 50, 62-78. [CrossRef]

40. Evett, S.; Schwartz, R.; Howell, T.; Baumhardt, R.; Copeland, K. Can weighing lysimeter ET represent surrounding field ET well enough to test flux station measurements of daily and sub-daily ET? Adv. Water Resour. 2012, 50, 79-90. [CrossRef]

41. Kustas, W.; Alfieri, J.; Evett, S.; Agam, N. Quantifying variability in field-scale evapotranspiration measurements in an irrigated agricultural region under advection. Irrig. Sci. 2015, 33, 325-338. [CrossRef] 
42. Heinlein, F.; Biernath, C.; Klein, C.; Thieme, C.; Priesack, E. Evaluation of simulated transpiration from maize plants on lysimeters. Vadose Zone J. 2017, 16, 1-16. [CrossRef]

43. Yang, F.; Zhang, Q.; Wang, R.; Zhou, J. Evapotranspiration measurement and crop coefficient estimation over a spring wheat farmland ecosystem in the Loess Plateau. PLoS ONE 2014, 9, e100031. [CrossRef]

44. Jiménez-Carvajal, C.; Ruiz-Peñalver, L.; Vera-Repullo, J.; Jiménez-Buendía, M.; Antolino-Merino, A.; Molina-Martínez, J. Weighing lysimetric system for the determination of the water balance during irrigation in potted plants. Agric. Water Manag. 2016, 183, 78-85. [CrossRef]

45. Duan, S.; Li, Z.; Leng, P. A framework for the retrieval of all-weather land surface temperature at a high spatial resolution from polar-orbiting thermal infrared and passive microwave data. Remote Sens. Environ. 2017, 195, 107-117. [CrossRef]

46. Li, X.; Yang, K.; Zhou, Y. Progress in the study of oasis-desert interactions. Agric. For. Meteorol. 2016, $230,1-7$. [CrossRef]

47. Holzman, M.E.; Carmona, F.; Rivas, R.; Niclos, R. Early assessment of crop yield from remotely sensed water stress and solar radiation data. ISPRS J. Photogramm. 2018, 145, 297-308. [CrossRef]

(C) 2018 by the authors. Licensee MDPI, Basel, Switzerland. This article is an open access article distributed under the terms and conditions of the Creative Commons Attribution (CC BY) license (http:/ / creativecommons.org/licenses/by/4.0/). 